\title{
AMPUTATION FOR REFLEX SYMPATHETIC DYSTROPHY
}

\author{
PATRICK W. DIEliSSEN. A. T. P. M. ClAASSEN, PETER H. J. M. VELDMAN. R. JAN A. GORIS
}

From the University Hospital, Nijmegen, The Netherlands

We have reviewed 28 patients with reflex sympathetic dystrophy (RSD) who had 34 amputations in 31 limbs. The amputations had been performed for untenable pain (5), recurrent infection (14) or to improve residual function (15). Only two patients were relieved of pain by amputation, and this could not be predicted. Ten of 14 patients were cured of infection and 9 of 15 patients had improvement of residual function.

In 28 of the amputations, RSD recurred in the stump, especially after amputation at a level which was not free from symptoms. Because of recurrence of RSD in the stump or severe hyperpathia only two patients wear a prosthesis. Despite this 24 patients were satisfied with the results.

J Bone Joint Surg /Br/ 1995:77-B:270-3.

Received 8 Jume 1994: Accepted 5 August 1994

Many different treatments have been reported for reflex sympathetic dystrophy (RSD), but most have little or only temporary success. They include physical therapy, the systemic administration of various drugs such as corticosteroids and calcitonin (Christensen, Jensen and Noer 1982; Gobelet, Waldburger and Meier 1992), and sympathetic nervous blockade, regionally by stellate or lumbar block or sympathectomy (Wang, Johnson and Ilstrup 1985).

The prognosis of RSD is uncertain because of lack of prospective studies, but it is known that a number of patients will become seriously incapacitated and some will have total loss of function of the affected extremity. In endstage RSD, new problems may develop such as recurrent infection, trophic ulceration and intractable pain. In a few cases, both the patient and the doctor may consider amputation.

RSD is known to occur in stumps after amputation (Farkas and Nemes 1975; Odderson and Czerniecki 1990;

P. W. Dielissen. Student in Medicine

A. T. P. M. Claassen. Student in Medicine

P. H. J. M. Veldman, MD. Resident

R. J. A. Goris, MD. PhD. Head

Department of Surgery. University Hospital. PO Box 9101, $6500 \mathrm{HB}$

Nijmegen. The Netherlands.

Correspondence should be sent to Dr P. H. J. M. Veldman at the Department of Surgery, PO Box 7777. 5500 MB Veldhoven. The Netherlands.

(1)1995 British Editorial Society of Bone and Joint Surgery

$0301-620 \times / 95 / 2956 \$ 2.00$
Isakov, Susak and Korzets 1992). Amputation as a therapy for RSD has been reported only incidentally (Rohrich, Stevenson and Piepgrass 1987: Eyres, Talbot and Harding 1990; Ritt and Jansen 1992: Erdmann and Wynn-Jones 1992) or mentioned briefly in the details of large series (Kiaer 1948; Omer and Thomas 1971; Poplawski, Wiley and Murray 1983; Jankovic and van der Linden 1988). We have found no information on the indications for or the results of amputation in RSD and have therefore studied our results retrospectively.

\section{PATIENTS AND METHODS}

We reviewed all patients who had an amputation because of RSD-related problems. For the diagnosis of RSD we required four of the following five criteria: unexplained diffuse pain, alteration in skin colour compared with the opposite limb, diffuse oedema, alteration in skin temperature relative to the other limb, and limitation of the active range of motion. Other criteria were occurrence or increase of these signs and symptoms after use of the affected limb, and their presence in an area much larger than that of the primary injury or operation, including parts distal to the primary injury. These diagnostic criteria are similar to those used in other studies on RSD (Kozin et al 1981; Christensen et al 1983) and were discussed previously by us (Veldman et al 1993).

Sixteen of the 28 patients studied were already under review at the Department of Surgery, Nijmegen University Hospital, eight responded to a request from the Dutch Association of RSD patients, and four were referred by other physicians who knew of the study.

Details of medical histories were taken from the hospital records, and when these were not available, from the patients and their physicians. Recent information was obtained by questionnaire and by interview in an outpatient clinic in Nijmegen or, if necessary, at home. We paid special attention to signs and symptoms of RSD before amputation, to activities in daily life (ADL) after amputation, to the use of prostheses and to the recurrence of RSD.

Proficiency in ADL was judged on the basis of six functions: eating and drinking, washing and dressing, fine motor activities, domestic activity and mobility indoors and out of doors. A scoring system was used to record the independence of the patient, ranging from complete independence with no assistance to total dependence on a third party. 
Table I. Results of amputation related to level

\begin{tabular}{|c|c|c|c|c|c|c|}
\hline & \multirow[b]{2}{*}{ Number } & \multirow{2}{*}{$\begin{array}{l}\text { RSD symptoms } \\
\text { at level of } \\
\text { amputation }\end{array}$} & \multirow{2}{*}{$\begin{array}{l}\text { Recurrence } \\
\text { of RSD in } \\
\text { stump }\end{array}$} & \multicolumn{2}{|l|}{ Prosthesis } & \multirow{2}{*}{$\begin{array}{l}\text { Patient } \\
\text { satisfaction }\end{array}$} \\
\hline & & & & Temporary & Content & \\
\hline Finger/ray & 11 & 10 & 10 & & - & 7 \\
\hline Forearm & 3 & 2 & 3 & 2 & - & 2 \\
\hline Upper arm & 1 & 1 & 1 & 1 & - & 0 \\
\hline Toe & 1 & 1 & 1 & - & - & 1 \\
\hline Below-knee & 2 & - & 1 & 2 & - & 1 \\
\hline Through-knee & 8 & 7 & 8 & 4 & - & 6 \\
\hline Above-knee & 8 & 3 & 4 & 3 & 2 & 7 \\
\hline Total & 34 & 24 & 28 & 12 & 2 & 24 \\
\hline
\end{tabular}

Table II. Results of amputation

\begin{tabular}{lcccc}
\hline Indication & Number & $\begin{array}{l}\text { Pain } \\
\text { relief }\end{array}$ & $\begin{array}{l}\text { Improvement of } \\
\text { residual function }\end{array}$ & $\begin{array}{l}\text { Cured } \\
\text { infection }\end{array}$ \\
\hline Pain & 5 & 2 & 2 & - \\
$\begin{array}{l}\text { Improvement of } \\
\text { residual function }\end{array}$ & 15 & 4 & 9 & 5 \\
Infection & 14 & 5 & 6 & 10 \\
Total & 34 & 11 & 17 & 15 \\
\hline
\end{tabular}

Statistical analysis used the chi-squared test with Yates' correction, recording a $\mathrm{p}$ value of less than 0.05 as significant.

\section{RESULTS}

Details of the results are given in Tables I and II.

Patients. A total of 34 amputations on 31 limbs had been performed in 28 patients, 4 men and 24 women. Three had had two limbs amputated and three had had two amputations on one limb. The ages of the patients ranged from 23 to 73 years (median 42 years). In 24 limbs (77\%), RSD had caused a cold limb from the start (primary cold), in six (19\%) the limb had been warm from the start, and one had had a normal skin temperature at the onset of RSD.

RSD had developed after trauma in 19 limbs $(61 \%)$, after surgery in five (16\%) and spontaneously in seven (23\%). At the time of amputation, RSD had been present for from 5 months to 18 years (median 2.5 years).

In comparison with a series of 829 patients suffering from RSD but not requiring amputation (Veldman et al 1993), more of the amputated patients had suffered from primary cold $(p<0.001)$, and from spontaneous onset of the syndrome $(p=0.001)$.

Treatment before amputation. All the patients had many different types of treatment before amputation. Sympathetic blocks had been performed in 28 limbs $(74 \%)$ before amputation giving some improvement in only a minority. Drugs known to scavenge toxic oxygen radicals had been given in 30 cases $(88 \%)$ in only six $(20 \%)$ of which was there some improvement. In general, the RSD in these cases appeared to be resistant to all forms of treatment. Some measures not only failed to give any improvement, but caused an increase in severity of RSD. Both physical therapy and surgery of the affected limb caused a deterioration of the signs and symptoms of RSD in most patients. Indications. Five amputations, all in the lower limb, had been performed for untenable pain, and only after repeated requests from the patients. All the patients had previously been treated without success by sympathetic blockade, scavengers of oxygen radicals, transcutaneous electroneurostimulation and pain-relieving drugs.

Fifteen amputations had been performed because the limb had become useless to the patient and obstructed residual function, for example, legs which had to be kept in a horizontal position continuously because dependency increased pain $(n=5)$ and ankylosed, hypersensitive fingers which impaired the use of the hand $(n=9)$. The initiative for amputation came from the physician in some cases, but from the patient in many others.

Fourteen amputations had been performed because of permanent or recurrent severe infection in the limb, often caused by streptococci or anaerobic bacteria which were resistant to antibiotic therapy.

Amputations. There were 15 amputations in the upper limb: three fingers, eight rays of the hand, three through the forearm and one above the elbow. Part of the leg had been amputated in 19 patients: one toe, two below-knee, eight through-knee and eight above-knee. In 24 patients, some of the symptoms of RSD had been present at the level of amputation, mostly in the more distal procedures.

In 16 cases, epidural anaesthesia had been started preoperatively; 25 patients had been given mannitol $10 \%$ at $1000 \mathrm{ml} / 24$ hours during the operation. In 13 cases $(38 \%)$ 
complications occurred related to the amputation; 11 had wound infection and 11 delayed healing. Both were more common after peripheral amputations, and in previously infected patients.

Amputation performed because of pain $(n=5)$ had produced a significant decrease in only two patients; one had no change and two an increase. After amputation for reasons other than pain $(n=29)$, pain was decreased in nine, unchanged in nine, but increased in 11. Only two patients had complete relief of pain after amputation. In 28 patients pain after amputation was due to recurrence of RSD in the stump, and 24 patients, mainly elderly, had phantom pain. Phantom sensation had occurred in 29 of the 34 amputations. Neither phantom pain nor phantom sensation was related to the symptoms of RSD at the level of amputation and was not prevented by epidural anaesthesia. When amputation had been performed at a level free from symptoms, pain more often decreased and less often increased. Infection. Infection had been cured in ten of the 14 patients who had had amputation for this reason; they all had proximal amputations. Of the other four patients with persisting infection, three had been cured by repeated excision and drainage combined with antibiotics, but the fourth after a ray amputation of the fourth and fifth fingers had required a vascularised free myocutaneous flap.

Residual function. Fifteen patients had undergone amputation with the aim of improving residual function. Nine patients thought that this had been achieved, but two had no improvement and four had lost some function. Amputation for reasons other than improvement of residual function had achieved an improvement in eight, no change in five and deterioration in six. Improvement was more common after proximal amputations, and when amputation had been performed at a symptom-free level.

Recurrence of RSD. RSD had recurred in the stump in 28 cases; two other patients had had significant pain not caused by RSD and two had developed RSD in another extremity. In all 19 patients had RSD in another extremity. Again, recurrence was more common after amputation at a level with RSD present. Recurrence of RSD in the stump was not related to the duration of symptoms before amputation, to the primary temperature at onset, the use of epidural anaesthesia preoperatively, or the use of mannitol perioperatively.

Prostheses. Twenty-two patients with proximal amputations had been fitted with prostheses, but only 14 ever used them because of persistent or recurrent RSD or stump hyperpathia. Twelve soon gave up and only two still wear a prosthesis after 7 and 20 months, respectively.

Function. Before developing RSD, 26 patients had fulltime employment. After amputation, only eight returned to their original occupation, and only three worked full-time. As regards activities of daily living, little was gained or lost by amputation. Some improvement was reported in washing, management of clothing, and domestic activities. Even when amputations had been performed to increase residual function, only $60 \%$ achieved improvement.

Patients' opinions. Twenty-four patients were satisfied with the result of their amputation (Table I). These included all amputations in which there was no recurrence of RSD, but also 20 of 28 patients in whom RSD had recurred or persisted. After distal amputations, 8 of 12 patients $(67 \%)$ were satisfied and after proximal amputations 16 out of 22 patients $(73 \%)$. Satisfaction was greater when the initiative to have an amputation was taken by the patient.

\section{DISCUSSION}

There are no other reports on amputation for RSD with which we can compare our results. We can, however, compare the amputated patients with our previously reported group of 829 patients (Veldman et al 1993). The ratio of female to male patients was 6 to 1 in amputees against 3 to 1 in the large series. Most patients were 30 to 50 years of age in both series. RSD in amputated patients had more often started as the primary cold type, and more often spontaneously. These findings agree with other reports that primary cold RSD has a more severe prognosis (Goris, Reynen and Veldman 1990) and that recurrent RSD is more often spontaneous in origin (Veldman 1995).

The relief of pain by amputation was achieved in a minority of patients, and it was not possible to identify before operation those who would have severe pain after. Phantom pain was experienced by $71 \%$ of the amputations and phantom sensations in $85 \%$, similar to the incidence reported after amputation for reasons other than RSD (Sherman, Sherman and Parker 1984; Jensen et al 1985; Iacono, Linford and Sandyk 1987). We found no relation to the level of amputation, the indication for amputation, or the preoperative administration of epidural anaesthesia. For these reasons, we do not recommend amputation for pain relief.

The best results can be expected after amputation for recurrent or persistent infection, with $71 \%$ success in our series. The level of amputation was decisive; when it had failed to control infection, the level had been too distal, involving a finger, ray or toe in most cases.

Amputation aimed to increase residual function achieved only limited gain. Most were performed for severe hyperpathia. The aim was to relieve the patient of the fear of painful contacts, and some were then able to use the residual functions present before amputation. Amputation to increase residual function is a valid indication, but the patient must be given realistic expectations. Operation should be at a well-chosen level and through healthy tissue to have a chance of success.

The recurrence of RSD in the stump or in other limbs made most patients unable to wear a prosthesis. Only two patients are using artificial limbs, but both have only a short follow-up. Amputation with the aim of increasing residual function by using a prosthesis is therefore not realistic. The level of amputation should be proximal; peripheral amputa- 
tions to enable the patient to wear a more functional prosthesis, do not succeed.

Many of the patients were satisfied with the result of amputation, despite the high incidences of phantom pain, recurrence of RSD and little gain in terms of function. It is possible that these patients felt that their situation was hopeless before amputation. Amputation had improved social function; despite persistent pain and incapacity, their infections were cured and painful contacts with the hyperpathic limb itself were eliminated.

Conclusions. For patients with severe, chronic RSD amputations should not be performed because of pain alone: relief cannot be predicted. Amputation to increase residual function or for severe incurable infection was more successful. It should be performed at a level free from signs and symptoms of RSD; more limited distal amputation of a finger, a ray or a toe is likely to fail. After amputation for RSD, it is unlikely that a prosthesis will be used.

We would like to thank the Department of Physical Therapy and Ergotherapy at the University Hospital. Nijmegen. for their help with the ADL questionnaire, and especially Mrs M Corstens-Mignot. Mrs M. A. van Kuyk. Mrs M. Oerlemans, J. M. G. Rutten MD, M. van Giestel MD and the Dutch Association for patients suffering from reflex sympathetic dystrophy.

No benefits in any form have been received or will be received from a commercial party related directly or indirectly to the subject of this article.

\section{REFERENCES}

Christensen K, Jensen EM, Noer I. The reflex dystrophy syndrome: response to treatment with systemic corticosteroids. Acta Chir Scand 1982:148:65.3-5.

Erdmann MW, Wynn-Jones CH. 'Familial' reflex sympathetic dystrophy syndrome and amputation. Injury 1992:23:136-8.

Eyres KS, Talbot IC, Harding ML. Amputation for reflex sympathetic dystrophy. Br J Clin Pract 1990:44:654-6.

Farkas TA, Nemes GA. A contribution to the morphology of Sudeck's syndrome. Z Orthop 1975:113:421-4.
Gobelet C, Waldburger M, Meier JL. The effect of adding calcitonin to physical treatment on reflex sympathetic dystrophy. Pain 1992;48:171-5.

Goris RJA, Reynan JAM, Veldman P. De posttraumatische dystrofie. In: Mourik JB van. Patka P. eds. Letsels van enkel en voet. Haren: Symposiumcommissie Chirurgie Nederland. 1990:435-6.

lacono RP, Linford J, Sandyk-R. Pain management after lower extremity amputation. Neurosurgery 1987:20:496-500.

Isakov E, Susak Z, Korzets A. Reflex sympathetic dystrophy of the stump in below-knee amputees. Clin J Pain 1992;8:270-5.

Jankovic J, van der Linden C. Dystonia and tremor induced by peripheral trauma: predisposing factors. J Neurol Neurosurg Psichiatr 1988:51:1512-9.

Jensen TS, Krebs B, Nielsen J, Rasmussen P. Immediate and long-term phantom limb pain in amputees: incidence. clinical characteristics and relationship to pre-amputation limb pain. Pain 1985:21:267-78.

Kiaer S. Remarks on the prognosis of the posttraumatic dystrophy of the extremities. Acta Orthop Scand 1948;17:253-69.

Kozin F, Soin JS, Ryan LM, Carrera GF, Wortmann RL. Bone scintigraphy in the reflex sympathetic dystrophy syndrome. Radiology 1981:138:437-43.

Odderson IR, Czerniecki JM. Reflex sympathetic dystrophy in an amputee: case study. Arch Phys Med Rehabil 1990:71:161-3.

Omer G, Thomas S. Treatment of causalgia: review of cases at Brooke General Hospital. Tex Med 1971:67:93-6.

Poplawski ZJ, Wiley AM, Murray JF. Post-traumatic dystrophy of the extremities: a clinical review and trial of treatment. J Bone Joint Surg [Am] 1983:65-A:642-55.

Ritt MJPF, Jansen WBJ. Armamputatie na posttraumtische dystrofic. Med J Delft 1992:4:220-3.

Rohrich RJ, Stevenson TR, Piepgrass W. End-stage reflex sympathetic dystrophy. Plast Reconstr Surg 1987;79:625-6.

Sherman RA, Sherman CJ, Parker I. Chronic phantom and stump pain among American veterans: results of a survey. Pain 1984:18:83-95.

Veldman PH. Clinical aspects of reflex sympathetic dystrophy. Doctoral thesis, Nijmegen, 1995:107-15.

Veldman PH, Reynen HM, Arntz IE, Goris RJ. Signs and symptoms of reflex sympathetic dystrophy: prospective study of 829 patients. Lancet 1993:342:1012-6.

Wang JK, Johnson KA, Ilstrup DM. Sympathetic blocks for reflex sympathetic dystrophy. Pain 1985:23:13-7. 